\title{
Tuberculosis in wild South American sea lions Otaria flavescens stranded in Chubut, Argentina
}

\author{
Carla Fiorito ${ }^{1,2}$, Jimena Marfil ${ }^{3}$, Elvira Falzoni ${ }^{3}$, Marcela Martínez Vivot ${ }^{3}$, \\ Martín Zumárraga $^{4}$, Daniel Lombardo ${ }^{2, *}$, Soledad Barandiaran ${ }^{3,5}$ \\ ${ }^{1}$ Consejo Nacional de Investigaciones Científicas y Técnicas, Centro para el Estudio de Sistemas Marinos \\ (CESIMAR-CONICET), U9120, Chubut, Argentina \\ ${ }^{2}$ Universidad de Buenos Aires. Facultad de Ciencias Veterinarias. Instituto de Investigación y Tecnología en Reproducción \\ Animal (INITRA), Cátedra de Histología y Embriología, C1427CWO, Buenos Aires, Argentina \\ ${ }^{3}$ Universidad de Buenos Aires. Facultad de Ciencias Veterinarias, Cátedra de Enfermedades Infecciosas, C1427CWO, \\ Buenos Aires, Argentina \\ ${ }^{4}$ Consejo Nacional de Investigaciones Científicas y Técnicas, Instituto de Agrobiotecnología y Biología Molecular, \\ Instituto Nacional de Tecnología Agropecuaria (IABIMO, INTA-CONICET), C1033AAE, Buenos Aires, Argentina \\ ${ }^{5}$ Consejo Nacional de Investigaciones Científicas y Técnicas (CONICET), C1425FQB, Buenos Aires, Argentina
}

\begin{abstract}
Pinniped tuberculosis, commonly caused by Mycobacterium pinnipedii, is a zoonotic disease reported in free-living and captive otariid species of the southern hemisphere. Currently, data concerning pinniped tuberculosis in South America are scarce, reinforcing the need for further studies of the disease in free-ranging pinnipeds. In this study, we investigated the presence of tuberculosis in South American sea lions Otaria flavescens (SASLs) stranded along the Chubut coastline (Argentina). Necropsies were performed in 9 SASLs, and tissue samples were collected for histopathology, bacteriology, and molecular diagnosis. Four SASLs showed enlarged tracheobronchial lymph nodes (TBLNs) with multifocal to coalescing granulomas. In these animals, a direct IS6110-PCR amplification confirmed the presence of a Mycobacterium tuberculosis complex member in TBLNs $(n=4)$ and lungs $(n=2)$, but the agent could not be further identified. In one SASL, Mycobacterium murale was isolated from lungs without lesions. This study confirms the presence of tuberculosis in SASLs from Chubut, where tourist activities promote close interaction with the animals, generating a potential risk to human health. Further research is currently focusing on addressing the prevalence of tuberculosis in wild SASLs, to assess the risk for public health and develop management strategies to avoid human infection.
\end{abstract}

KEY WORDS: Pinnipeds - Tuberculosis - Mycobacterium tuberculosis complex - Zoonosis · Public health

\section{INTRODUCTION}

Tuberculosis in pinnipeds is typically caused by a member of the Mycobacterium tuberculosis complex (MTBC) named Mycobacterium pinnipedii (Cousins et al. 2003). Tuberculosis due to $M$. pinnipedii has been reported in otariid species of the southern hemisphere, both in the wild and in captivity (Cousins et al. 2003, Arbiza et al. 2012, Jurczynski et al. 2012,
Martins Melo et al. 2019, Roe et al. 2019), and also in a variety of other mammalian species (Cousins et al. 2003, Jurczynski et al. 2011, Kriz et al. 2011, Loeffler et al. 2014, Roe et al. 2019). Mycobacterium pinnipedii infection has also been detected in humans who were in direct contact with infected pinnipeds or were exposed to an environment contaminated with the bacteria (Kiers et al. 2008), highlighting the importance of this disease as a public health concern. 
In wild pinnipeds, a presumptive diagnosis of tuberculosis can be made during necropsies, based on the presence of caseous lesions or granulomasin the lungs and thoracic organs, liver, spleen, peritoneum, and lymph nodes. Histologically, granulomatous lesions are typical, with a central area of caseous necrosis, a variable degree of mineralization, and acid-fast bacilli (AFB) within macrophages or extracellularly in the caseous core (Roe et al. 2019). Culture is the gold standard for etiological diagnosis, but it may take up to $8 \mathrm{wk}$ to grow, or yield false negative results if the bacteria are dead (Proaño-Pérez et al. 2011). PCR is a useful tool to identify mycobacteria from cultures, fresh tissues, and formalin-fixed paraffin-embedded samples (Roe et al. 2019). Specific primers that target the insertion sequence 6110 (IS6110) element were successfully applied to detect members of the MTBC in pinnipeds (Zumárraga et al. 1999, Cousins et al. 2003), and recently a PCR assay for the region of difference 2 (RD2) was used to identify $M$. pinnipedii in samples with moderate to large numbers of AFB (Roe et al. 2019). Molecular typing (e.g. spoligotyping) confirms that $M$. pinnipedii belongs to a unique genotypic group within the MTBC (Cousins et al. 2003).

The first case of tuberculosis in a wild South American sea lion Otaria flavescens (SASL) was described by Bernardelli et al. (1996) in a stranded animal from the northern coast of Argentina. Since then, tubercu- losis due to $M$. pinnipedii was reported as the cause of death in 4 SASLs stranded in Uruguay and Brazil (Arbiza et al. 2012, de Amorim et al. 2014, Martins Melo et al. 2019). The prevalence and epidemiology of tuberculosis in SASL populations from South America warrant further investigation in order to assess the impact both for SASL populations and for human health, due to the zoonotic potential of the disease.

The SASL has a wide distribution along the Atlantic coasts of South America, but the north and central Patagonian coast holds approximately $72 \%$ of the species abundance within the Atlantic Ocean, with more than 40 colonies and 175000 individuals (Romero et al. 2017). In Chubut, SASLs are appealing targets for ecotourism, and diving/snorkeling with SASLs is a growing tourist activity that promotes close contact with the animals, posing a potential risk to human health. In this study, we investigated the presence of tuberculosis in stranded SASLs from Chubut Province.

\section{MATERIALS AND METHODS}

\subsection{Samples}

From 2013 to 2018, 9 dead-stranded SASLs were examined (Table 1) as part of a marine mammal health surveillance project. Carcasses were in good

Table 1. Case details and summary of results in stranded South American sea lions. F/A: female adult; M/A: male adult; F/S: female subadult; M/S: male subadult; F/J: female juvenile; M/J: male juvenile. HP: histopathological; TBLN: tracheobronchial lymph node; Neg: negative; Pos: positive; CGL: chronic granulomatous lymphadenitis; AFB: acid-fast bacilli; np: not performed

\begin{tabular}{|c|c|c|c|c|c|c|c|c|}
\hline Case ID & $\begin{array}{l}\text { Sex/age } \\
\text { class }\end{array}$ & $\begin{array}{c}\text { Body } \\
\text { condition }\end{array}$ & Organ & $\begin{array}{l}\text { Gross } \\
\text { lesions }\end{array}$ & HP lesions & $\begin{array}{l}\text { AFB/ } \\
\text { smear }\end{array}$ & Culture & $\begin{array}{c}\text { Direct IS6110 } \\
\text { PCR }\end{array}$ \\
\hline NEC15 & F/A & Good & $\begin{array}{l}\text { Lung } \\
\text { TBLN }\end{array}$ & $\begin{array}{c}\text { Absent } \\
\text { Enlarged granulomas }\end{array}$ & $\begin{array}{l}\text { Absent } \\
\text { CGL }\end{array}$ & $\begin{array}{l}\mathrm{np} \\
\mathrm{np}\end{array}$ & $\begin{array}{l}\mathrm{np} \\
\mathrm{np}\end{array}$ & $\begin{array}{l}\text { Neg } \\
\text { Pos }\end{array}$ \\
\hline NEC16 & $\mathrm{F} / \mathrm{S}$ & Poor & $\begin{array}{l}\text { Lung } \\
\text { TBLN }\end{array}$ & $\begin{array}{l}\text { Absent } \\
\text { Absent }\end{array}$ & $\begin{array}{l}\text { Absent } \\
\text { Absent }\end{array}$ & $\begin{array}{l}\text { Neg } \\
\text { Neg }\end{array}$ & $\begin{array}{l}\text { Neg } \\
\text { Neg }\end{array}$ & $\begin{array}{l}\text { Neg } \\
\text { Neg }\end{array}$ \\
\hline NEC22 & $\mathrm{M} / \mathrm{A}$ & Poor & $\begin{array}{l}\text { Lung } \\
\text { TBLN }\end{array}$ & $\begin{array}{c}\text { Absent } \\
\text { Enlarged granulomas }\end{array}$ & $\begin{array}{l}\text { Absent } \\
\text { CGL }\end{array}$ & $\begin{array}{l}\text { Pos } \\
\text { Pos }\end{array}$ & $\begin{array}{l}\text { Pos } \\
\text { Neg }\end{array}$ & $\begin{array}{l}\text { Neg } \\
\text { Pos }\end{array}$ \\
\hline NEC28 & $\mathrm{F} / \mathrm{S}$ & Good & $\begin{array}{l}\text { Lung } \\
\text { TBLN }\end{array}$ & $\begin{array}{l}\text { Absent } \\
\text { Absent }\end{array}$ & $\begin{array}{l}\text { Absent } \\
\text { Absent }\end{array}$ & $\begin{array}{l}\text { Neg } \\
\text { Neg }\end{array}$ & $\begin{array}{l}\text { Neg } \\
\text { Neg }\end{array}$ & $\begin{array}{l}\text { Neg } \\
\text { Neg }\end{array}$ \\
\hline NEC29 & $\mathrm{F} / \mathrm{J}$ & Poor & $\begin{array}{l}\text { Lung } \\
\text { TBLN }\end{array}$ & $\begin{array}{l}\text { Absent } \\
\text { Absent }\end{array}$ & $\begin{array}{l}\text { Absent } \\
\text { Absent }\end{array}$ & $\begin{array}{l}\text { Neg } \\
\text { Neg }\end{array}$ & $\begin{array}{l}\text { Neg } \\
\text { Neg }\end{array}$ & $\begin{array}{l}\text { Neg } \\
\text { Neg }\end{array}$ \\
\hline NEC 30 & $\mathrm{~F} / \mathrm{J}$ & Poor & $\begin{array}{l}\text { Lung } \\
\text { TBLN }\end{array}$ & $\begin{array}{c}\text { Absent } \\
\text { Enlarged granulomas }\end{array}$ & $\begin{array}{l}\text { Absent } \\
\text { CGL }\end{array}$ & $\begin{array}{l}\text { Pos } \\
\text { Pos }\end{array}$ & $\begin{array}{l}\text { Neg } \\
\text { Neg }\end{array}$ & $\begin{array}{l}\text { Pos } \\
\text { Pos }\end{array}$ \\
\hline NEC31 & $\mathrm{M} / \mathrm{S}$ & Good & $\begin{array}{l}\text { Lung } \\
\text { TBLN }\end{array}$ & $\begin{array}{c}\text { Absent } \\
\text { Enlarged granulomas }\end{array}$ & $\begin{array}{l}\text { Absent } \\
\text { CGL }\end{array}$ & $\begin{array}{l}\text { Pos } \\
\text { Pos }\end{array}$ & $\begin{array}{l}\text { Neg } \\
\text { Neg }\end{array}$ & $\begin{array}{l}\text { Pos } \\
\text { Pos }\end{array}$ \\
\hline NEC68 & $\mathrm{M} / \mathrm{J}$ & Poor & $\begin{array}{l}\text { Lung } \\
\text { TBLN }\end{array}$ & $\begin{array}{l}\text { Absent } \\
\text { Absent }\end{array}$ & $\begin{array}{l}\text { Absent } \\
\text { Absent }\end{array}$ & $\begin{array}{l}\text { Neg } \\
\text { Neg }\end{array}$ & $\begin{array}{l}\text { Neg } \\
\text { Neg }\end{array}$ & $\begin{array}{l}\text { Neg } \\
\text { Neg }\end{array}$ \\
\hline NEC69 & $\mathrm{M} / \mathrm{J}$ & Poor & $\begin{array}{l}\text { Lung } \\
\text { TBLN }\end{array}$ & $\begin{array}{l}\text { Absent } \\
\text { Absent }\end{array}$ & $\begin{array}{l}\text { Absent } \\
\text { Absent }\end{array}$ & $\begin{array}{l}\text { Neg } \\
\text { Neg }\end{array}$ & $\begin{array}{l}\text { Neg } \\
\text { Neg }\end{array}$ & $\begin{array}{l}\text { Neg } \\
\text { Neg }\end{array}$ \\
\hline
\end{tabular}


preservation status (carcass condition code 2 or 3 ) and necropsies were performed following standardized protocols (Geraci \& Lounsbury 2005). Most carcasses were necropsied within $48 \mathrm{~h}$ of stranding, except NEC16, which was kept frozen at $-20^{\circ} \mathrm{C}$ for $11 \mathrm{~d}$ until necropsy was performed, and NEC29 and NEC30, which were kept frozen for several months (stranding date unknown). During necropsies, most organs were sampled to determine the cause of death and for other ongoing research. Special attention was given to explore gross pathological signs of tuberculosis (granulomatous lesions) in the thoracic and abdominal organs. Samples with and without macroscopic lesions were collected and then fixed in $10 \%$ neutral buffered formalin, while unfixed samples were stored at $-20^{\circ} \mathrm{C}$. For NEC15, only fixed samples were taken.

\subsection{Histological examination}

Fixed tissues were routinely processed for histology, sectioned at $5 \mu \mathrm{m}$, and stained with hematoxylin and eosin and Ziehl-Neelsen (ZN) stain (Biopack ${ }^{\circledR}$ ). Samples of calcified granulomas were demineralized with aqueous nitric acid $5 \%$ for $24 \mathrm{~h}$ after fixation to perform histopathological examination. Images were captured using a Leica DM2500 LED ${ }^{\circledR}$ microscope with coupled camera (Leica model DCC-310X ${ }^{\circledR}$ ), and an image capture system supported by Leica LASZ software.

\subsection{Bacteriology}

Smears from frozen tissues were stained according to the ZN method (Biopack ${ }^{\circledR}$ ) for direct observation of AFB. For culture, tissue samples were macerated and decontaminated using Petroff's method with sodium hydroxide $(\mathrm{NaOH})$, cultured into Stonebrink and Löwenstein-Jensen medium and then incubated for 8 to $10 \mathrm{wk}$ at $37^{\circ} \mathrm{C}$ (Proaño-Pérez et al. 2011). The ZN stain (Biopack ${ }^{\circledR}$ ) was used to evaluate the presence of AFB in positive cultures.

\subsection{Molecular diagnostics}

DNA from ZN-positive cultures was obtained by thermal lysis and stored at $-20^{\circ} \mathrm{C}$. Total DNA extraction was performed in frozen lungs and thoracic lymph nodes (with and without granulomatous lesions) using the PureLink ${ }^{\mathrm{TM}}$ Genomic DNA Mini Kit
(Invitrogen) according to the manufacturer's protocol. For NEC15 (only formalin-fixed samples), $5 \mu \mathrm{m}$ thick sections from the paraffin block were dewaxed, rehydrated, and treated with Proteinase $\mathrm{K}$ in lysis buffer for DNA extraction. The DNA obtained was stored at $-20^{\circ} \mathrm{C}$ until PCR assay.

A rapid PCR amplification for the IS6110 fragment was performed using the primers INS1 (CGT GAG GGC ATC GAG GTG GC) and INS2 (GCG TAG GCG TCG GTG ACA AA) (Hermans et al. 1991) and the Touch-Down cycling program published by Zumárraga et al. (2005), using the DNA extracted from tissues and colony lysates. Distilled water and DNA from $M$. bovis AN5 strain were used as negative and positive controls, respectively. Colonies that were positive for IS6110-PCR were subsequently subjected to spoligotyping (Mapmygenome) for species differentiation (Kamerbeek et al. 1997). In AFB-positive isolates that were negative to IS6110-PCR, amplification of the 16S rRNA ribosomal gene fragment was performed (Kirschner et al. 1993). The PCR products were purified using the Illustra DNA and Gel Band Purification Kit (GE Healthcare) and sequenced. The obtained sequences were compared with those available in the National Center for Biotechnology Information (NCBI) database using the Basic Local Alignment Search Tool (BLAST) (https:// blast.ncbi.nlm.nih.gov/Blast.cgi) and the Ribosomal Database Project (https://rdp.cme.msu.edu/seqmatch) to identify mycobacterial species.

\section{RESULTS}

\subsection{Gross and histological findings}

Grossly, NEC15, NEC22, NEC30, and NEC31 each showed an enlarged firm tracheobronchial lymph node (TBLN), with multifocal whitish caseous granulomas and central mineralization (Fig. 1). Granulomas were absent in the lungs, pleura, abdominal organs, and other lymph nodes. Histopathological examination of TBLNs revealed multifocal to coalescing granulomas with central caseous necrosis surrounded by fibrous tissue and variable amounts of lymphocytes, plasma cells, and macrophages. Mineralization was frequent, and numerous multinucleated giant cells were observed at the medulla. Multinucleated giant cells and macrophages showed a moderate amount of pale brown pigment inside the cytoplasm (Fig. 2). No AFB were observed. Gross and histopathological examination did not reveal granulomatous lesions or AFB in the other 5 SASLs. 


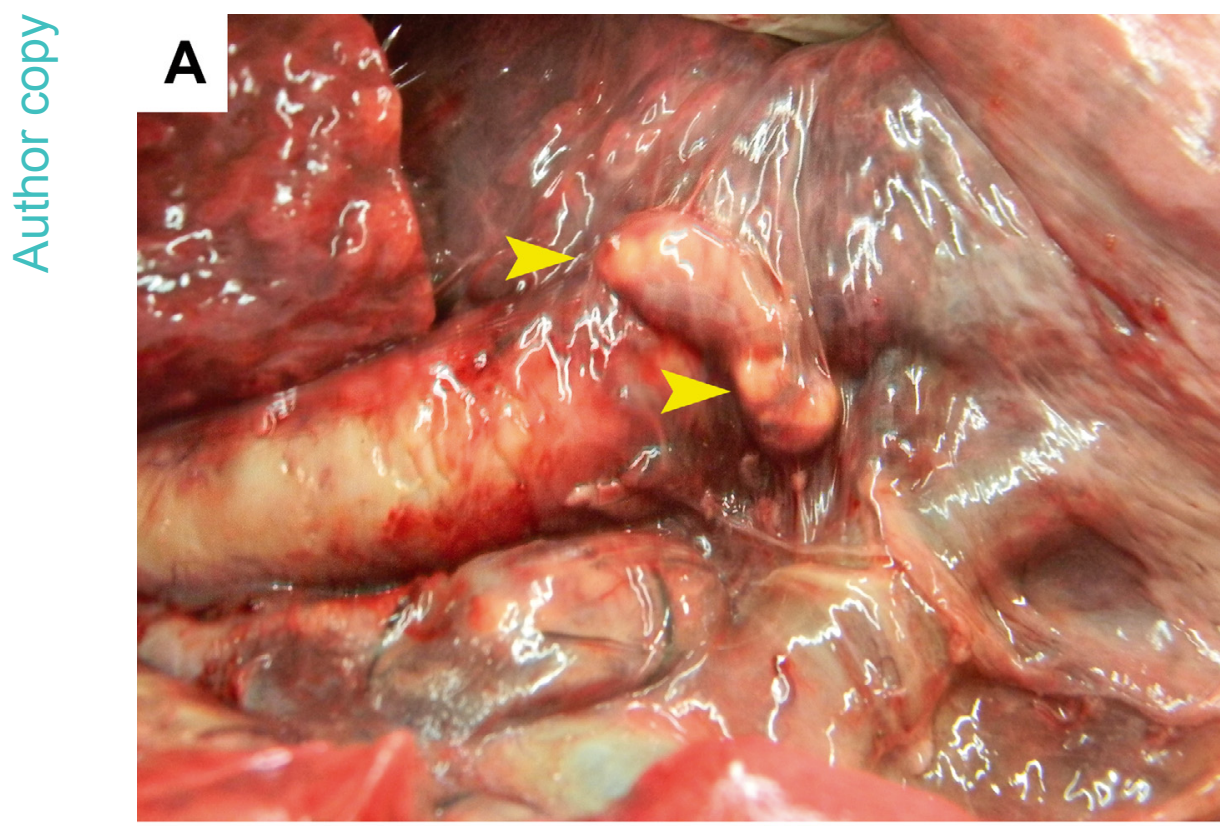

\subsection{Molecular analysis}

The IS6110 PCR from tissues was positive in TBLNs from NEC15 and NEC22, and in TBLN and lungs from NEC30 and NEC31 (see the Appendix, Fig. A1). The IS6110 PCR yielded negative results in the remaining tissue samples. The DNA extracted directly from tissues was poor in quality and quantity for the spoligotyping assay, so it was not possible to identify the species within the MTBC. The mycobacteria isolated from the lung sample of NEC22 was negative for IS6110 $\mathrm{PCR}$, but was identified as $\mathrm{Myco-}$ bacterium murale by sequencing a fragment of the 16S rRNA ribosomal gene, which showed $100 \%$ coverage and $99 \%$ identity when compared to known $M$. murale sequences in the NCBI database (please contact authors for accession numbers).

\section{DISCUSSION}

This study confirms the presence of tuberculosis due to a member of the MTBC in 4 SASLs in the Chubut Province, providing the first report of the disease in wild SASLs of the Patagonian region. The gross and histological lesions found in TBLNs were similar to those described previously in pinnipeds, with typical granulomas showing central caseous necrosis, variable amounts of fibrosis, mineralization, and multinucleated giant cells (Jurczynski et al. 2012, Roe et al. 2019). Tuberculosis lesions were found only in thoracic lymph nodes, rein-

\subsection{Bacteriology}

Impression smears from NEC22, NEC30, and NEC31 (Table 1) showed few to moderate numbers of AFB with ZN staining (Fig. 2F), while the other samples were negative. Culture remained negative in almost all samples after $10 \mathrm{wk}$, whereas 1 colony was isolated in lung samples from NEC22. forcing the hypothesis that inhalation is the main pathway of infection in pinnipeds (Roe et al. 2019). While none of the SASLs in this study had pulmonary lesions consistent with active tuberculosis, AFB were present in impression smears of lung tissue, and PCR confirmed the presence of an MTBC organism in the lungs, indicating the potential for transmission via their respiratory secretions. The disease transmission 
응
ㅇ
을
들
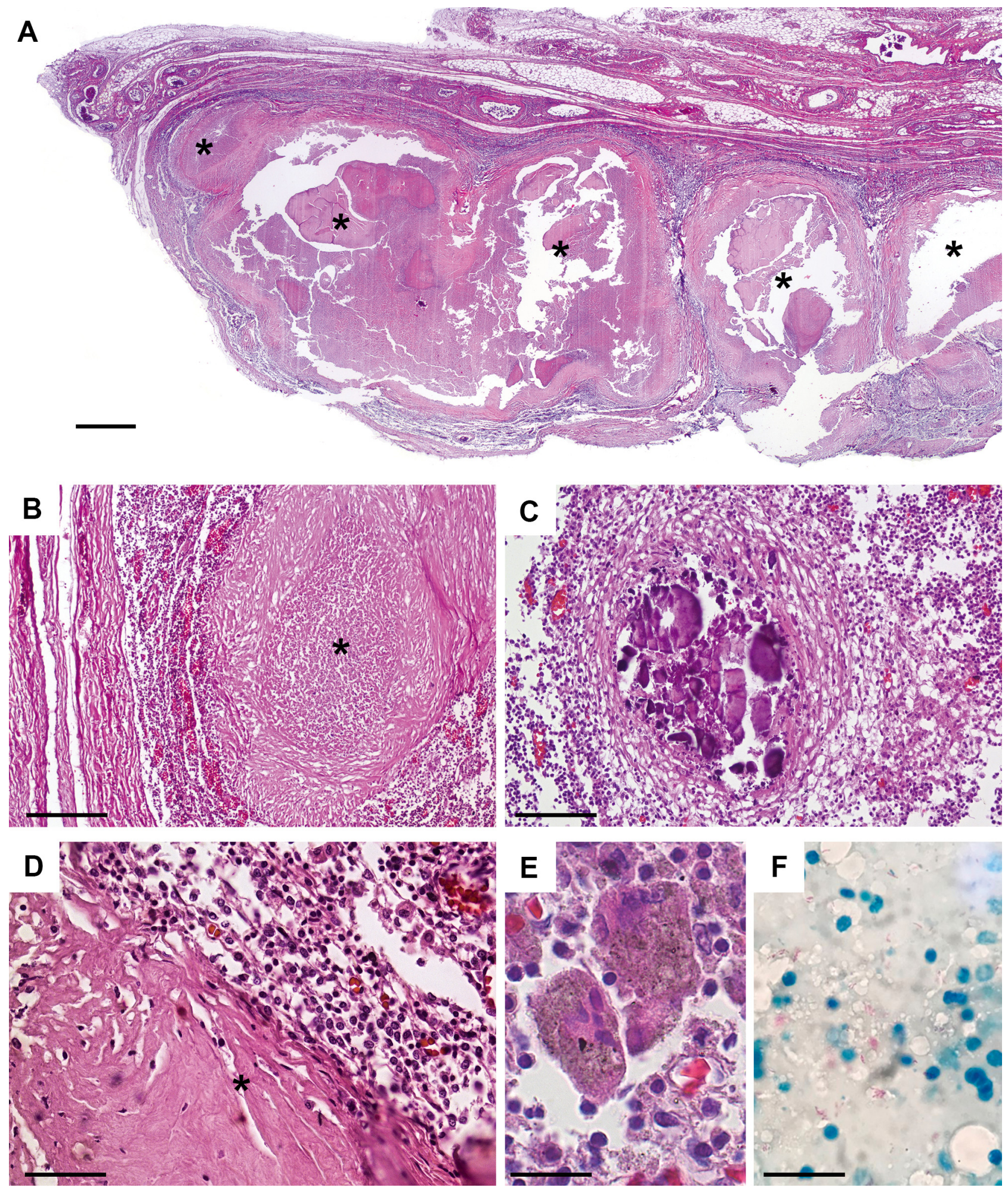

Fig. 2. (A-E) Histopathological lesions in tracheobronchial lymph nodes (TBLNs). Hematoxylin and eosin. (A) Multifocal to coalescing granulomas (asterisks), NEC31. Demineralized sample, $2.5 \times$ magnification; scale bar $=1 \mathrm{~mm}$. (B) Large granuloma with central areas of caseous necrosis (asterisk) NEC15. 10x; scale bar $=200 \mu \mathrm{m}$. (C) Small granuloma with central mineralization, NEC22. 20x; scale bar $=100 \mu \mathrm{m}$. (D) Fibrous tissue (asterisk) and infiltrate with lymphocytes, plasma cells, and macrophages, NEC31. 40x; scale bar $=50 \mu \mathrm{m}$. (E) Multinucleated giant cells, NEC22. 40 $x_{i}$ scale bar $=50 \mu \mathrm{m}$. (F) Acid-fast-bacilli, impression smear of TBLN, NEC31. Ziehl-Neelsen stain. 100x; scale bar $=20 \mu \mathrm{m}$ 
in wild pinnipeds could be favored by close contact during the congregation, and may occur during coughing, sneezing, or naso-nasal contact (Arbiza et al. 2012).

Tuberculosis appears to be an endemic disease and a common cause of mortality in some pinniped populations (Arbiza et al. 2012, Roe et al. 2019). However, the cause of death in the 4 positive SASLs was not related to tuberculosis, as granulomatous lesions were found solely in TBLNs. In positive SASLs, the causes of death were attributed to acute trauma (NEC15) and septicemia (NEC31), while in 2 SASLs the cause remains unknown. Further studies are required to investigate the actual impact of tuberculosis on wild SASL health.

Mycobacterial culture remains the diagnostic gold standard test, being also necessary for subsequent genotyping. We were not able to isolate the MTBC member, possibly due to the disease stage and/or the number and viability of bacilli in the samples, considering the time lag between sample collection and culture (Proaño-Pérez et al. 2011). Nevertheless, the presence of an MTBC member was confirmed in 4 SASLs by direct IS6110 PCR. The PCR was positive in TBLN samples with granulomas as well as in lung samples from 2 SASLs (NEC30 and NEC31) without macroscopic or microscopic lesions. Similar findings were reported previously by Arbiza et al. (2012), who isolated $M$. pinnipedii from pinnipeds without gross lesions. While a presumptive diagnosis of tuberculosis in SASLs is made on the basis of finding characteristic macroscopic lesions (Jurczynski et al. 2012), our results reinforce the importance of testing samples without gross lesions for pinniped tuberculosis diagnosis.

The non-tuberculous mycobacteria (NTM) Мycobacterium murale was isolated in a lung sample from NEC22, suggesting a case of coinfection. Some NTM have been reported to cause infection in marine mammals (Clayton et al. 2012) and lung diseases in humans (Porvaznik et al. 2017), so future work should investigate the role of $M$. murale as a potential pathogenic agent for SASLs.

The prevalence and epidemiology of tuberculosis in Patagonian SASL populations require further investigation, but assessing the actual prevalence of tuberculosis in free-living pinnipeds could be difficult. In dead pinnipeds, the prevalence of tuberculosis could be underestimated because small lesions may be limited to a single deep lymph node and/or some animals could be positive without gross lesions (Arbiza et al. 2012). Thus, it is important to reinforce the use of standard postmortem protocols to perform a systematic collection of lungs and lymph node samples (with and without gross lesions), to improve the reliability of the results. Antemortem diagnosis was performed in captive SASLs using a combination of different tests in order to achieve the highest sensitivity (Jurczynski et al. 2012). Because most tests are not validated for use in wild animals, and the use of multiple diagnostic tests is impractical for wild pinniped populations, efforts should be directed to validate a fast and efficient antemortem diagnostic method (e.g. a specific serological test) for tuberculosis detection in wild pinnipeds.

Pinniped tuberculosis represents a serious concern for human health, mostly for people who work in close contact with these animals (Kiers et al. 2008). Appropriate biosafety practices must be implemented to prevent mycobacterial infection when live pinnipeds are manipulated, and also during postmortem examination. Touristic activities that promote close contact with wild pinnipeds should be included within groups of risk. In Chubut, diving/snorkeling with SASLs is a growing touristic attraction. Between 8000 and 10000 people visit the SASL colony of Punta Loma Natural Reserve each year (Ministerio de Turismo y Áreas Protegidas del Chubut, period: 2014-2018). The SASL tourism industry is regulated by national and state laws, based on the impact of SASL-human interactions. These laws were established to protect the SASLs from human impacts and prevent injuries to people (e.g. SASL bites) (Dans et al. 2017). Although direct contact with animals is not allowed, close interactions between people and SASLs are frequent (e.g. face to face approach, kisses). Given the confirmation of tuberculosis by a MTBC member in SASLs in the Chubut Province, the risk of tuberculosis and other zoonotic disease transmission must be considered in future regulations.

Acknowledgments. The authors thank the Chubut Coastal Wildlife Network for reporting South American sea lion stranding. Samples were collected in full compliance with specific federal permits issued by the Dirección de Fauna y Flora Silvestre and the Subsecretaría de Turismo y Áreas Protegidas, Chubut, Argentina (permit Numbers 019/2018SSG and 022-SsCyAP/18). This work was supported by The Environmental Conservation Fund Grant 2019 (FOCA 2019) from Galicia Bank and Williams Foundation.

\section{LITERATURE CITED}

Arbiza J, Blanc A, Castro-Ramos M, Katz H, Ponce de León A, Clara M (2012) Uruguayan pinnipeds (Arctocephalus australis and Otaria flavescens): evidence of influenza virus and Mycobacterium pinnipedii infections. 
In: Romero A, Keith EO (eds) New approaches to the study of marine mammals. INTECH, London, p 151-182

Bernardelli A, Bastida R, Loureiro J, Michelis H, Romano MI, Cataldi A, Costa E (1996) Tuberculosis in sea lions and fur seals from the south-western Atlantic coast. Rev Sci Tech 15:985-1005

Clayton LA, Stamper MA, Whitaker BR, Hadfield CA, Simons B, Mankowski JL (2012) Mycobacterium abscessus pneumonia in an Atlantic bottlenose dolphin (Tursiops truncatus). J Zoo Wildl Med 43:961-965

Cousins DV, Bastida R, Cataldi A, Quse V and others (2003) Tuberculosis in seals caused by a novel member of the Mycobacterium tuberculosis complex: Mycobacterium pinnipedii sp. nov. Int J Syst Evol Microbiol 53:1305-1314

Dans SL, Crespo EA, Coscarella MA (2017) Wildlife tourism: underwater behavioral responses of South American sea lions to swimmers. Appl Anim Behav Sci 188:91-96

de Amorim DB, Casagrande RA, Alievi MM, Wouters F and others (2014) Mycobacterium pinnipedii in a stranded South American sea lion (Otaria byronia) in Brazil. J Wildl Dis 50:419-422

Geraci JR, Lounsbury VJ (2005) Marine mammals ashore: a field guide for strandings, 2nd edn. National Aquarium in Baltimore, Baltimore, MD

KHermans PWM, van Soolingen D, Bik EM, de Haas PEW, Dale JW, van Embden JDA (1991) Insertion element IS987 from Mycobacterium bovis BCG is located in a hotspot integration region for insertion elements in Mycobacterium tuberculosis complex strains. Infect Immun 59:2695-2705

Jurczynski K, Lyashchenko KP, Gomis D, Moser I, Greenwald R, Moisson P (2011) Pinniped tuberculosis in Malayan tapirs (Tapirus indicus) and its transmission to other terrestrial mammals. J Zoo Wildl Med 42:222-227

Jurczynski K, Lyashchenko KP, Scharpegge J, Fluegger M and others (2012) Use of multiple diagnostic tests to detect Mycobacterium pinnipedii infections in a large group of South American sea lions (Otaria flavescens). Aquat Mamm 38:43-55

Kamerbeek J, Schouls L, Kolk A, van Agterveld M and others (1997) Simultaneous detection and strain differentiation of Mycobacterium tuberculosis for diagnosis and epidemiology. J Clin Microbiol 35:907-914

Kiers A, Klarenbeek A, Mendelts B, Van Soolingen D,
Koëter G (2008) Transmission of Mycobacterium pinnipedii to humans in a zoo with marine mammals. Int $\mathrm{J}$ Tuberc Lung Dis 12:1469-1473

Kirschner P, Springer B, Vogel U, Meier A and others (1993) Genotypic identification of mycobacteria by nucleic acid sequence determination: report of a 2-year experience in a clinical laboratory. J Clin Microbiol 31:2882-2889

Kriz P, Kralik P, Slany M, Slana I and others (2011) Mycobacterium pinnipedii in a captive Southern sea lion (Otaria flavescens): a case report. Vet Med 56:307-313

Loeffler SH, de Lisle GW, Neill MA, Collins DM, PriceCarter M, Paterson B, Crews KB (2014) The seal tuberculosis agent, Mycobacterium pinnipedii, infects domestic cattle in New Zealand: epidemiologic factors and DNA strain typing. J Wildl Dis 50:180-187

* Martins Melo A, da Silva Filho RP, von Groll A, Reis AJ and others (2019) Tuberculosis caused by Mycobacterium pinnipedii in a wild South American sea lion Otaria flavescens stranded in southern Brazil. Dis Aquat Org 133:189-194

* Porvaznik I, Solovič I, Mokrý J (2017) Non-tuberculous mycobacteria: classification, diagnostics, and therapy. Adv Exp Med Biol 944:19-25

*Proaño-Pérez F, Benitez-Ortiz W, Desmecht D, Coral M and others (2011) Postmortem examination and laboratory-based analysis for the diagnosis of bovine tuberculosis among dairy cattle in Ecuador. Prev Vet Med 101:65-72

Roe WD, Lenting B, Kokosinska A, Hunter S and others (2019) Pathology and molecular epidemiology of Mycobacterium pinnipedii tuberculosis in native New Zealand marine mammals. PLOS ONE 14:e0212363

Komero MA, Grandi MF, Koen-Alonso M, Svendsen G and others (2017) Analysing the natural population growth of a large marine mammal after a depletive harvest. Sci Rep 7:5271

* Zumárraga MJ, Bernardelli A, Bastida R, Quse V and others (1999) Molecular characterization of mycobacteria isolated from seals. Microbiology 145:2519-2526

Kumárraga MJ, Meikle V, Bernardelli A, Abdala A, Tarabla H, Roman AI, Cataldi A (2005) Use of touch-down polymerase chain reaction to enhace the sensitivity of Mycobacterium bovis detection. J Vet Diagn Invest 17: 232-238 


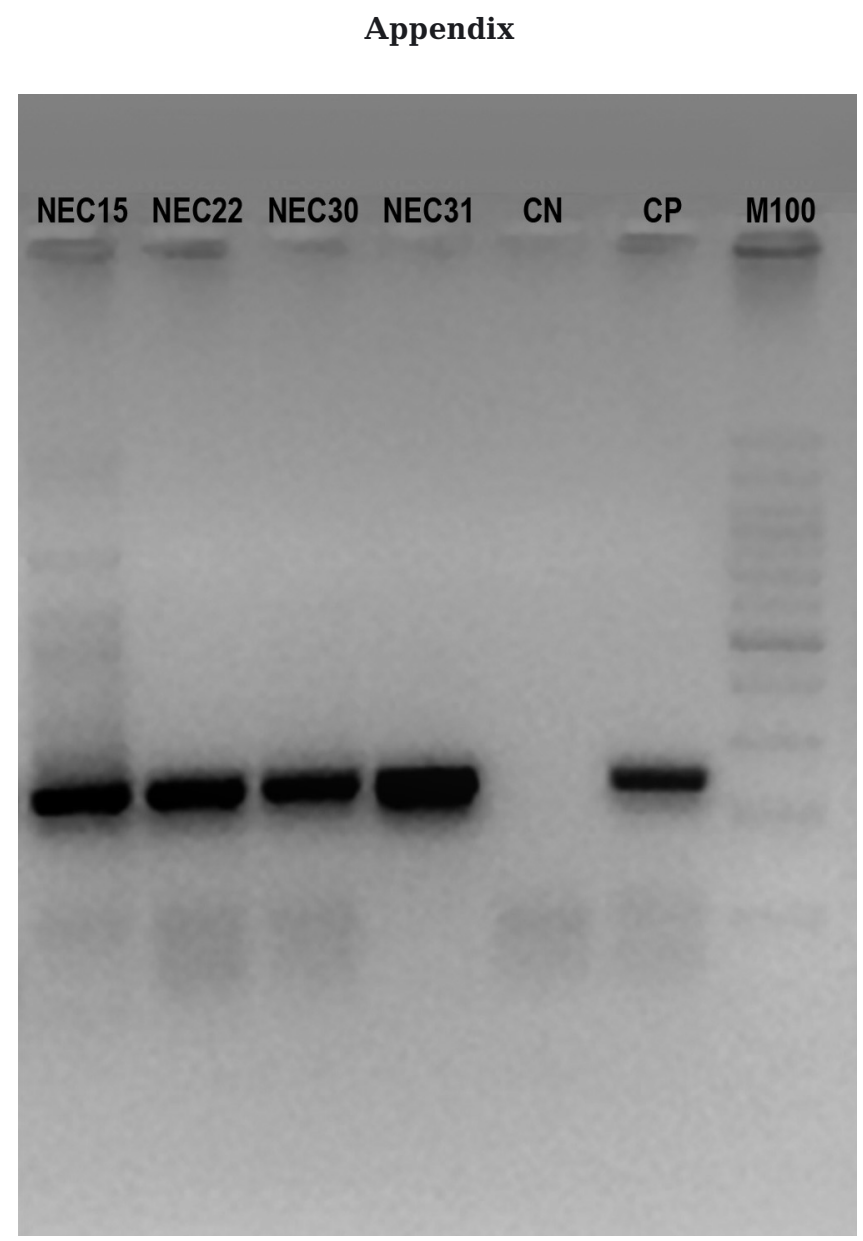

Fig. A1. Agarose gel electrophoresis of PCR-IS6110 products. DNA fragments of $245 \mathrm{bp}$ for NEC15, NEC22, NEC30, and NEC31. NC: negative control (distilled water); PC: positive control (M. bovis AN5); M100: 100 bp DNA Ladder, Promega

Editorial responsibility: Stephen Raverty, Abbotsford, British Columbia, Canada
Submitted: October 22, 2019; Accepted: July 29, 2020 Proofs received from author(s): November 4, 2020 